\title{
The Development of Integrative Assessment Model for the Subject of Bahasa Indonesia in Senior High School Students
}

\author{
Aco Karumpa \\ Universitas Negeri Makassar, Jln. Bonto Langkasa, Kampus Gunung Sari, Makassar, South Sulawesi, Indonesia \\ Paturungi Parawangsa \\ Universitas Negeri Makassar, Jln. Bonto Langkasa, Kampus Gunung Sari, Makassar, South Sulawesi, Indonesia \\ Mansyur \\ Universitas Negeri Makassar, Jln. Bonto Langkasa, Kampus Gunung Sari, Makassar, South Sulawesi, Indonesia \\ Muhammad Saleh \\ Universitas Negeri Makassar, Jln. Bonto Langkasa, Kampus Gunung Sari, Makassar, South Sulawesi, Indonesia
}

\begin{abstract}
The purpose of this research is to develop an integrative assessment model for the subject of Bahasa Indonesia that is effective for high school students. This research was a research and development with some stages proposed by Borg and Gall \& Sugiyono. Development of the model begun with preliminary studies, preparation of prototypes, validity test conducted by experts, testing of models in schools, and the analysis of testing results. The calculation for the validity of the model conducted by using Aiken analysis showed some findings. First, the validity of attitude assessment showed that $0.96>0.83$ (very valid). Second, the validity of the knowledge assessment showed that $1.79>0.73$ (very valid). Third, the validity of skills assessment showed that $0.865>0.860$ (valid). In addition, the calculation for the model performed by using Coefficient Cohen' Kappa also showed some findings as follows. First, the reliability of attitude assessment showed that $0,87>0$, 70 (very reliable). Second, the reliability of the knowledge assessment showed that $1.79>0.73$ (very reliable). Third, the reliability of skills assessment showed that $0,71>0,70$ (reliable). The calculation for the practicality of the model conducted by five teachers proves several things. First, the practicality of attitude assessment showed that 3, 6 (very practical). Second, the practicality of the knowledge assessment showed that 3, 5 (very practical). Third, the practicality of skills assessment showed that 3, 7 (very practical). These findings demonstrate that integrative assessment model is very effective for assessing the ability of high school students.
\end{abstract}

Index Terms—integrative assessment, attitude assessment, knowledge assessment, skill assessment

\section{INTRODUCTION}

Student learning outcomes for the subject of Bahasa Indonesia can be known through an assessment process. If learning uses communicative-integrative approach, the assessment also must use a communicative-integrative assessment. Communicative learning means that students are required to be able to communicate using language properly. Language learning paradigm is a consequence of the implementation of language learning assessment. Language learning assessment should be performed by using integrative assessment models. Government Regulation No. 19 in 2005 on Standards Assessment of Education Article 63 Paragraph (1) states that assessment of education at primary and secondary levels consists of (a) assessment by educators, (b) an assessment by the education unit, and (c) assessment by the government. Assessments carried out in relation to the school learning activities include formative assessment and summative assessment. However, if it is associated with Government Regulation No. 19 of 2005, in addition to the two above assessment, it is also known national exam. It is the assessment by conducted by the government. Formative assessment takes place during the teaching and is used to provide feedback into the learning process. Summative assessment occurs at the end of the lesson and is used to provide information about how many students who have managed to understand how good the quality of teaching and learning that has been performed by the teacher (Gipps, 2003, p. 7). Assessment models which are used both by teachers, schools and government have not been able to provide integrated information regarding the students' learning outcome for the subject of Bahasa Indonesia in senior high school. Assessment models used by the teacher and the school do not guarantee the existence of valuation models that have the quality and characteristics of good assessment (reliability, validity, and practicality). The purpose of this research is to develop an integrative assessment model for the subject of Bahasa Indonesia that is effective in senior high school. The theoretical benefits of this research are to contribute to the development of the theory of language assessment, in particular, the assessment of Bahasa Indonesia ability in schools. The practical benefit is to 
produce an integrative assessment product for the subject of Bahasa Indonesia so it can be a reference for teachers, schools, and government in carrying out the assessment.

\section{REVIEW OF RELATED LITERATURE}

\section{A. Evaluation of Education}

There are three terms that have a close relationship and are difficult to be distinguished, namely (1) evaluation, (2) measurement, and (3) assessment. According to Rashid, et al. (2009) evaluation is the process of determining the value of the performance and student learning outcomes based on information obtained through the assessment. Assessment is the process of collecting information or data used to make decisions about learning (students, curriculum, programs, and policies). Measurement is the determination procedure of the figures in a systematic way to express individual characteristics such as cognitive, affective, and psycho motor skill.

There are two types of assessments conducted in schools, namely: formative assessment and summative assessment. Cowie and Bell (1999) reveal that "formative assessment is the process used by teachers and children to recognize to pupil learning, in order to enhance that learning during the activity or task". In addition, Garrison and Ehringhaus (accessed 10 November 2012) explained that summative assessment is a means to measure the content standards achieved by learners. Summative assessment is a tool to assist in evaluating the effectiveness of the program, improving the quality of schools, aligning curriculum or placing students in a particular program.

\section{B. The Nature of Language Learning}

In essence language is a communication tool. Learners who learn a language is expected to be able to communicate with the high level of mastery and fluency. In relation to the curriculum of Indonesian subjects today, learning Indonesian conducted by some learning principles presented by Gagne (1979, p. 70), namely contiguity, repetition, and reinforcement. The application of these principles can make learners achieve the high level of mastery and fluency.

Richards (2006, p. 2) explains the aspects of language knowledge as communicative competence. These aspects are communicative aspects, social aspects, discourse aspects, and strategic aspects. Learning a language that includes these four aspects is called contextual learning and teaching (CLT).

\section{Standard Assessment}

Assessment standards using standardized tests such as the Test of Proficiency in Indonesia (Uji Kemahiran Berbahasa Indonesia/UKBI), Test of English as Foreign Language (TOEFL) and International English Language Testing System (IELTS) are the reference in the development of integrated assessment models. UKBI test is a means of assessment of proficiency for Indonesian speakers. UKBI test development is intended to have the same functionality as the TOEFL test, namely as a means of assessment in language teaching. The characteristic of UKBI test is planning a test that focuses on the use of Indonesian in the realm not in the area of language use. In contrast to the TOEFL test, the test design refers to the use of English in North America (Banerjee et al., 2003). The composition of the material about those two kinds of tests is almost identical although the approach to testing communicative language is very different. The TOEFL test has been operating for 40 years without having no truck with the communicative revolution. UKBI test is influenced by the evolution of the concept of linguistic theory of communicative language pioneered by Dell Hymes in the early 1970s (Davis, 2003).

\section{Communicative Assessment}

Communicative competence theory is a theory of knowledge and ability. A person cannot develop language test method without defining what is meant by the language. Furthermore, Canale and Swain in Body and Langham (2000, p. 3) describe three competencies required of a person in achieving the ability and proficiency. The first is grammar, including knowledge of lexical items and the rules of morphology, syntax, semantics and phonology. The second is sociolinguistic competence. It consists of sociocultural and discourse rules. The third is strategic competence related to the communication strategy of verbal and non-verbal that can be applied to the action in order to compensate for disruptions in communication.

Learners who have a good communicative test results are characterized by the ability of learners to use the language in real communication. Someone who has a language proficiency is not only characterized by its ability to learn the language theory but also the extent to which a person is able to communicate fluently in everyday life.

\section{E. Thematic Integrative Assessment}

Indonesian language learning in high school is a learning-based integrative thematic. Integrative term refers to two things, namely external and internal integration. External integration is learning materials of Bahasa Indonesia that are associated with other disciplines, such as environment, religion, socio-cultural, political, economic, and law. Internal integration is to integrate the four components of language skills in whole or in part of a linguistic context.

Indonesian language learning is learning that is packaged in the form of themes (thematic). Rusman (2010, p. 249) explains that the theme is a medium to introduce various concepts or competencies to students as a whole. Building thematic aims at unifying the curriculum content in an intact unit so that it makes and integrated and meaningful 
learning material. In addition, it can be easily understood by students. If the Indonesian learning materials use thematic integrative principle, the implementation of assessment of student learning outcomes should also use the principle of thematic integrative.

The integrative assessment evaluates aspects of linguistics and aspects of language skills through a comprehensive assessment rather than through a separate assessment. Thus, the assessment using the integrative approach realizes the aspects of language and skills in an integrated manner (Oller, 1979). The integration is intended to test the ability of learners to use two or more language skills simultaneously.

\section{F. Good Assessment Criteria}

Abramson (1979) mentions four good assessment criteria, namely: (1) quality, (2) efficiency, (3) differential value, and (4) satisfaction. Quality is the assessment given to students to give effect to increase student motivation. The highquality assessment gives the desired effect and erodes undesirable effects.

There are some good assessment criteria according to Anderson et al. (No Year: 9). They are (1) validity and coherence, (2) reproducibility or consistency, (3) feasibility, (4) equivalent, (5) effects of assessment, (6) catalytic effect, and (7) acceptability.

People who carry out language testing can investigate language skills through statistical analysis and through criteria related to the study to link the information produced by these tests. The use of statistical analysis in the past received less attention. In the previous approach, language testing is a test of discrete elements of the target language (lexical or grammatical item). The use of statistical perspective in language testing in the United States in the 1980s (Bachman and Palmer 1990) [4] aims at establishing validity. It was seen primarily as a matter of statistical validation whether the tests are measuring a construct on individuals regardless of other construction.

Assessment of teachers has high validity in relation to the content and construction (Gipps, 2003, p. 123). Furthermore Gipps suggested that if the teacher's assessments are used for formative purposes which then results in improving learning, the assessment can be said to have consequential validity (2003, p. 124).

In addition to the analysis of the validity, reliability analysis is very important. Assessment tools that have the principle of reliability are the assessment tools that provide a stable and consistent information (Phelan and Wren, 2005). Furthermore, although a test device is said to be valid and reliable, a number of practical considerations must be taken into account. Practical considerations that are intended are economic factors, the factors in relation to exam preparation, assessment, and interpretation.

\section{METHOD}

\section{A. The Type of the Research}

This study was a research and development (R \& D) by using the stages of research proposed by Borg and Gall (2003) and Sugiyono (2008).

\section{B. Research Design}

The research design that combines the model of Borg and Gall \& Sugiyono (2003) could be described as follows:

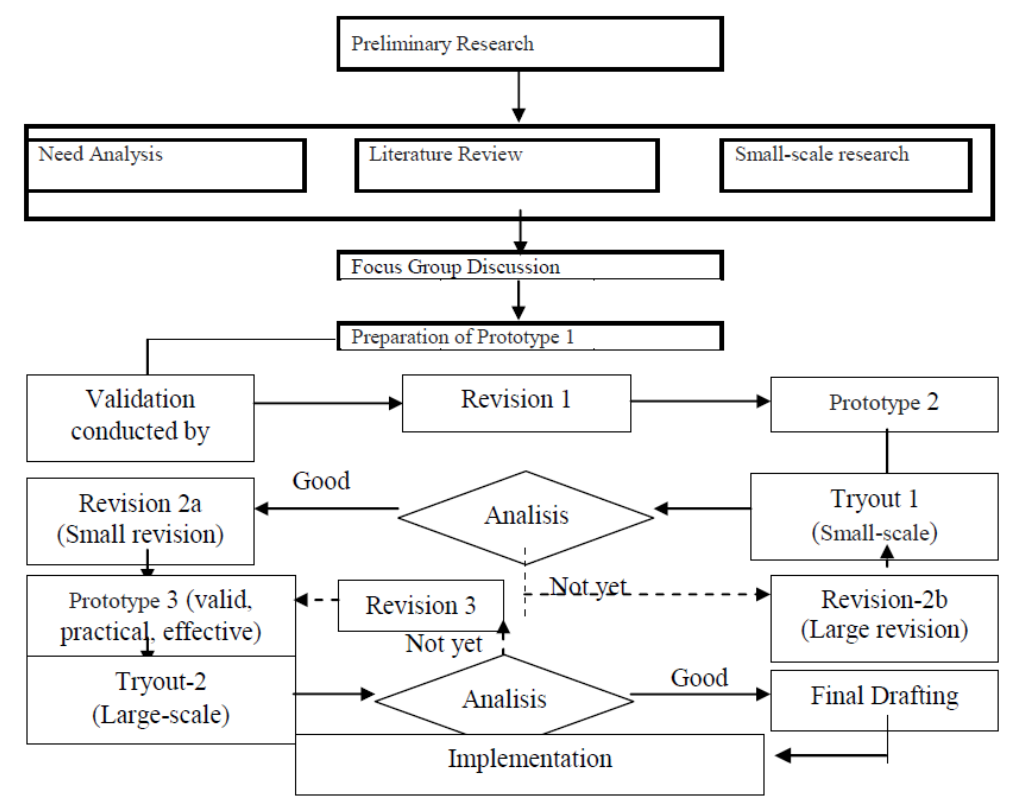

Figure 1. Research Design 


\section{Data and the Source of Data}

Data and sources of data in this study were:

a. Preliminary research including needs analysis, literature review, and small-scale research with the source data obtained from interviews (principals, teachers, supervisors), a standard test (UKBI, TOEFL, IELTS), document assessment used by teachers;

b. Prototype I compiled based on data from focus group discussion involving teachers, principals, supervisors;

c. Validation of the model obtained through validation conducted by linguist and expert in evaluation of education;

d. The results of trying out I in which the source data was obtained through trying out the model to 75 high school students.

e. Prototype II prepared based on expert recommendations and analysis of the results of the tryout I;

f. Results of trying out II in which the source of data were obtained through trying out the model to 75 high school students.

\section{Techniques of Data Analysis}

a. Analysis of the validity of the model using the formula proposed by Aiken (1985), namely:

$\mathrm{V}=\mathrm{S} /[\mathrm{n}(\mathrm{c}-1)]$

b. Analysis of the reliability level of the model using the percentages of agreements proposed by Cohen's Kappa. (Mansour, 2009, p. 134), namely:

$K=\quad \sum \mathrm{f}_{0}-\sum \mathrm{f}_{\mathrm{e}}$

c. Analysis of the level of practicality models through the opinion of five practitioners (teachers).

\section{RESULTS}

\section{A. Procedure of Developing the Model}

Development of a model refers to the concept of R \& D Model proposed by Gall \& Borg combined with the concept of R \& D Model proposed by Sugiyono (2008). The development of an integrated assessment models is through several stages that are coherent and systematic, from the preliminary study stage (a needs analysis, literature studies, and smallscale research), Focus Group Discussion (FGD), to the preparation of prototype.

Furthermore, there have been prototypes that are produced through expert validation, revision, testing, and the analysis of the effectiveness of the model. The development phase is described in the effectiveness of the model. These stages produce the final draft that then became the final model.

\section{B. The Components of the Integrative Assessment}

The involvement of teachers, principals, and supervisors in a focus group discussion (FGD) aims at building a prototype assessment of student learning outcomes at the high school level that can provide full information. In the FGD, the researchers analyzed the needs of teachers, conducted a study on the theories of educational evaluation and evaluated the learning of Bahasa Indonesia.

The results of focus group discussion produce prototype integrative assessment as illustrated in Figure 2.

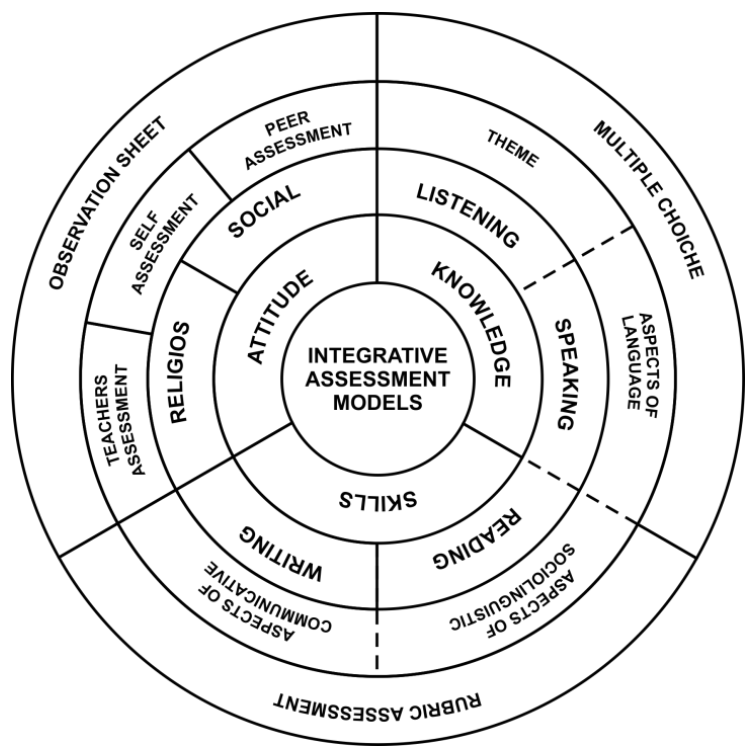

Figure 2. The Integrative Assessment Model 
Based on figure 2 above, there are some points that can be explained concerning the integrative assessment models for Indonesian subject in senior high school as follows:

1. The integrative assessment consisted of three domains, namely attitude assessment, knowledge assessment, and skills assessment.

2. Attitude assessment was carried out using the observation sheet to record the results of teacher assessment, selfassessment, and peer assessment.

3. Knowledge assessment is implemented using assessment tools such as tests. This assessment tool includes knowledge assessment that will assess listening, speaking, reading, and writing skills.

4. For listening skill, the researchers used the form of questions consisting of main idea, title, and intrinsic elements of literary works, the topic of conversation, conclusions, detailed information, suggestion, implications, assumed question, purpose, problems, and speaker's view.

5. For the speaking skill, the researchers use the form of inquiry consisting of expressing the contents of figures, tables, charts, and graphs, interviewing and making dialogue, retelling, doing a speech, concluding report, and announcing based on the given illustrations.

6. For reading skill, the researchers used the form of questions about (a) topic or theme, facts and opinions, (b) main idea, (c) detailed information, (d) conclusion, (e) purpose, (f) title, (g) tables, graphs, and charts, (h) intrinsic and extrinsic elements of literary works, (i) drama, and (j) couplets.

7. For the writing skills, researchers used a form of questions consisting of: (a) the formation of words, (b) syntax, (c) semantic, (d) paragraphs (e) syllogism, (f) constructing sentences into solid paragraphs, (g) a speech, (h) scientific papers, (i) official letter, (j) users, and (k) literary criticism.

8. The assessment of language skills was conducted by using assessment tools such as assessment rubric. The assessment rubric for each language skills consists of (a) the competence of skills, (b) the aspect of observation, (c) observation point, (d) scoring, and (e) assessment scale.

9. For the assessment of listening skills, the researchers looked at several aspects, namely: (a) the content of the response, (b) the systematic response, (c) the effectiveness of the sentence, and (d) ethics.

10. For the assessment of speaking skills, researchers observed some aspects, such as (a) the accuracy of the information, (b) the relationship of information, (c) the accuracy of the structure, (d) the accuracy of vocabulary, and (e) the style of pronunciation and fluency.

11. For the assessment of reading skills, researchers also observed some aspects, such as (a) reading techniques, (b) timeliness, and (c) the content of the text.

12. For the assessment of writing skills, researchers observed some aspects, such as (a) the content of the idea, (b) the organization of content, (c) grammar and sentence, (d) diction, and (e) spelling.

Integrative assessment model consists of attitude assessment (Wiggins, 1990); knowledge assessment (Richard, 2006, p. 2 and Bachman, 1990, p. 84) and skills assessment (Fuchler 2002 and Edelson, curtains and Pea, 1999). This assessment tool is expected to become effective assessment tool used in schools. The effectiveness of the model can be determined through expert validation, testing, and statistical analysis. The statistical analyzes provide information about the level of validation of the model, the level of reliability of the model, and the level of practicality models. Thirdeffectiveness analysis can be described as follows.

\section{The Level of Validation}

The level of validation in integrative assessment can be seen in the following table.

TABLE 1.

LEVEL OF VALIDATION OF THE MODEL AND ITS CATEGORY

\begin{tabular}{|c|c|c|c|c|}
\hline No. & Components of integrative assessment & $\begin{array}{l}\text { Validity Coefficient } \\
\text { (V) }\end{array}$ & value standard V & Category \\
\hline 1. & attitude assessment & & & \\
\hline & a. $\quad$ Teacher Assessment & 0,833 & \multirow{3}{*}{0,83} & valid \\
\hline & b. Self-assessment & 1,01 & & very valid \\
\hline & c. Peer assessment & 1,06 & & very valid \\
\hline \multirow[t]{5}{*}{2.} & Knowledge assessment & & & \\
\hline & a. $\quad$ Listening & 1,85 & \multirow{4}{*}{0,73} & very valid \\
\hline & b. $\quad$ Speaking & 1,83 & & very valid \\
\hline & c. $\quad$ Reading & 1,73 & & very valid \\
\hline & d. Writing & 1,75 & & very valid \\
\hline \multirow[t]{5}{*}{3.} & Skill Assessment & & & \\
\hline & a. $\quad$ Listening & 0,86 & \multirow{4}{*}{0,86} & valid \\
\hline & b. $\quad$ Speaking & 0,86 & & valid \\
\hline & c. $\quad$ Reading & 0,86 & & valid \\
\hline & d. Writing & 0,86 & & valid \\
\hline
\end{tabular}

The applications of Aiken analysis is to find out the validity of teacher assessment sheet with a total score $=58$, the number of assessors $=2$, the number of categories $=4$. Therefore, the value of $\mathrm{V}$ is $58 /[2(4-1)]=0.833$. According to 
Aiken (1985) if the number of assessment item is 8 , the minimum standards for validity coefficient value (V) is 0.830 . The validity coefficient value (V) for all components of the integrative assessment is greater than the standard value so that all the items can be valid and very valid.

\section{The Level of Reliability}

To analyze the reliability, the researchers used inter-rater reliability (gwet, 2012, p. 32). The results of the analysis of the level of reliability of the three components of integrative assessment can be seen in the following table.

TABLE 2.

THE LEVEL OF RELIABILITY AND ITS CATEGORY

\begin{tabular}{|c|c|c|c|c|}
\hline No. & Components of integrative assessment & $\begin{array}{l}\text { Reliability Coefficient } \\
\text { (R) }\end{array}$ & value standard $\mathrm{R}$ & Category \\
\hline 1. & attitude assessment & & & \\
\hline & a. $\quad$ Teacher Assessment & 0,87 & \multirow{3}{*}{0,70} & reliable \\
\hline & b. Self-assessment & 0,87 & & reliable \\
\hline & c. Peer assessment & 1,00 & & Very reliable \\
\hline \multirow[t]{5}{*}{2.} & Knowledge assessment & & & \\
\hline & a. $\quad$ Listening & 0,80 & \multirow{4}{*}{0,70} & reliable \\
\hline & b. $\quad$ Speaking & 0,87 & & reliable \\
\hline & c. $\quad$ Reading & 0,87 & & reliable \\
\hline & d. $\quad$ Writing & 0,80 & & reliable \\
\hline \multirow[t]{5}{*}{3.} & Skill Assessment & & & \\
\hline & a. $\quad$ Listening & 0,71 & \multirow{4}{*}{0,70} & reliable \\
\hline & b. $\quad$ Speaking & 0,71 & & reliable \\
\hline & c. Reading & 0,71 & & reliable \\
\hline & d. $\quad$ Writing & 0,71 & & reliable \\
\hline
\end{tabular}

Based on the above table, it shows that all the components of integrative assessment have a value of reliability coefficient $(\mathrm{R})$ that is greater than the standard value of $\mathrm{R}$ so that all of the components can be said reliable and the integrative assessment is highly reliable.

\section{E. The Level of Practicality}

The results of the practicality can be seen in the following table

TABLE 3.

THE ASSESSMENT RESULT OF PRACTICALITY

\begin{tabular}{|c|c|c|c|c|}
\hline No. & $\begin{array}{l}\text { Components of Integrative } \\
\text { Assessment }\end{array}$ & Mean Score & Category & Scale of Category \\
\hline 1. & Attitude assessment & 3,6 & very practical & \multirow{3}{*}{$\begin{array}{l}3,5-4,0=\text { very practical } \\
2,5-3,49=\text { Practical } \\
1,5-2,49=\text { quite practical } \\
0-1,49=\text { not practical }\end{array}$} \\
\hline 2. & Knowledge assessment & 3,4 & very practical & \\
\hline 3. & Skill assessment & 3,7 & very practical & \\
\hline
\end{tabular}

Based on the above table, it shows that the three components of integrative assessment have a very practical category. Thus, an integrative assessment model is very practical to use at senior high schools.

\section{DISCUSSION}

This integrative assessment models were developed to meet the needs assessments on the subject of Bahasa Indonesia in senior high school. The approach used in language learning can influence the use of language assessment. Learning and language assessment in the 1975 curriculum for senior high school used a discrete approach. This approach considers language as the components that stand alone as revealed by Oller (1979). Discrete assessment is used by the conventional understanding of the language (Djiwandono, 2011). The 1984 curriculum used an integrative approach. This approach considered that language learning involved two or three elements of language. Assessment with an integrative approach relied on the incorporation of various types of abilities and language elements in doing language tests that are still in the area of structural linguistics (Djiwandono, 2011).

Furthermore, the implementation of the 1994 curriculum in senior high school used a pragmatic approach both in learning and in the assessment of language. In the beginning, the pragmatic approach was learning the language based on grammar ability. This approach was then developed, and it became the ability to understand the context of discourse based on linguistic context (such as sentence structure, phrases, and words) and extra-linguistic aspects (such as the shape of events, thoughts, feelings, and perceptions). The understanding of language that only relies on the ability of grammar often encounters obstacles to understanding it. Therefore, the language elements and the context of external languages need to be associated (Oller, 1979). In the 2004 curriculum, the subject of Bahasa Indonesia in senior high school uses a communicative approach both in language learning and in language assessment. This approach is focused on students' ability to communicate intelligently. Therefore, students not only know the theory of language and grammar but also can use the language in formal and non-formal communication. Implementation of the ability to 
communicate in the language assessment has several elements such as linguistic, sociolinguistic, discourse and strategic competence (Davis, 2003). Learning and assessment of language based on the 2006 curriculum and the 2013 curriculum implements Contextual Teaching and Learning (CTL) approach. This approach primarily relies on the use of the communicative approach.

Integrative assessment models developed by Borg and Gall (2003) and Sugiyono (2008) consists of attitude, knowledge, and skills aspect. Integrating these three elements can shape the character and linguistic competence of students. The students have not only theoretical ability and communicative ability but also speaking ethics. This integrative assessment model refers to the elements proposed by Davis (2003) and adds an element of language attitudes. Thus, this assessment model reaches the integrative, pragmatic, communicative approach, and CTL approach.

This integrative assessment model is very appropriate to be used as the assessment tool for the subject of Bahasa Indonesia in senior high school without being bound by the application of the curriculum that is always changing. It is proved by the effectiveness consisting of validity, reliability, and practicality that have been tested.

\section{CONCLUSION}

The development of integrative assessment model has been validated by experts, tested on some high school students, and analysed by using descriptive statistics. Results of the content validation performed by experts of the integrative assessment model (attitude, knowledge and skills assessment) show a very high level of validation. The results of construction validation based on statistical analysis also show a very high level of validation. The results of reliability analysis of the integrative assessment models show a high degree of reliability. The results of the analysis of the practicality of the integrative assessment model show a very high level of practicality. Integrative assessment model that meets the requirements of validity, reliability and practicality suggests that this model is very effective to be used in senior high school.

This integrative assessment model can provide the results of objective and fair assessment for learners. Therefore, this integrative assessment model can be used as a reference for schools and government to carry out the assessment for the subject of Bahasa Indonesia in senior high school. Furthermore, the development of this model does not refer strictly to one curriculum so teachers can adjust the applicable curriculum. This model is expected to follow the development of flexible curriculum.

\section{REFERENCES}

[1] Abramson, J. H. (1979). The Four Basic Types of Evaluation: Clinical Review, Clinical Trial, Program Reviews, and Program Trials. Public Health Reports, Vol. 94, May-June.

[2] Aiken, Lewis R. (1985). Content Validity and Reliability of Single Items or Questionnaires. Educational and Psychological Measurement, (45), (p. 131-142).

[3] Anderson, Brownie, etc. (no date). Criteria of Good Assessment Context. Draft Makalah. Ottawa Conference.

[4] Bachman, L. F., \& Palmer, A. S. (1990). Consideration in Language Testing. Oxford: Oxford University Press.

[5] Banerjee, dkk., (2003). Test Review. Language Testing 20 (1). (p. 111-123).

[6] Boddy, Nick Miyata and Langham Clive S. (2000). Communicative Language Testing-an Attainable Goal? The British Council, Tokyo (Online) (http://eltj.oxfordjournals.org.ezproxy. flinders.edu.aucontent572198. full.pdf+html. (accessed 12 November 2012).

[7] Borg, R. Walter and Gall, Meredith D. (2003). Educational Research; An Introduction. London: Longman.

[8] Cowie, Bronwen, and Bell, Beveley. (1999). A Model of Formative Assessment in Science Education. Assessment in Education, 6 (1), (p. 102-116).

[9] Davis, A. (2003). Three Heresies of Language Testing Research. Language Testing 20 (4). (p. 355-368).

[10] Edelson, Daniel C., Gordin, Douglas N, and Pea, Roy D. (1999). Addressing the Challenges of Inquiry-Based Learning Through Technology and Curriculum Design. Journal of the Learning Sciences, Vol. 8: (p. 3-4).

[11] Fulcher, Glenn. (2002). The Communicative Legacy in Language Testing. English Language Institute, University of Surrey, Guildford, Surrey GU2 7XH, UK, (Online) (www.elsevier.com/locate/system. accessed 5 November 2012).

[12] Gagne, M. Robert and Briggs, Leslie J. (1979). Principles of Instructional Design, Second Edition. New York: Florida State University.

[13] Garrison, Catherine \& Ehringhous, Michael. Formative and Summative Assessments in the Classroom. National Middle School Association. (Online) (www.nmsa.org.614-895-4730. accessed 10 November 2012).

[14] Gipps, Caroline V. (2003). Beyond Testing: Towards a Theory of Educational Assessment. London-Washington, D.C.: The Falmer Press.

[15] Gwet, Kilem L. (2012). Handbook of Inter-Rater Reliability. The Defenitive Guide to Measuring the Extent of Agreement Among Raters. Gaithersburg USA: Advanced Analytics, LLC.

[16] Mansyur. (2009). Pengembangan Model Assessment for Learning pada Pembelajaran Matematika di SMP. Disertasi. Yogyakarta: Program Pascasarjana UNY.

[17] Oller, John W. (1979). Language Tests at School. London: Longman.

[18] Phelan, Colin \& Wren, Julie. (2005). Exploring Reliability in Academic Assessment. (Online) (http://www.uni.edu/chfasoa/reliabilityandvalidity. htm). (accessed 20 November 2012).

[19] Rasyid, Harun, dkk. (2009). Asessmen Perkembangan Anak Usia Dini. Yogyakarta: Multi Pressindo.

[20] Richards, J.C. (2006). Communicative Language Teaching Today. New York: Cambridge University Press.

[21] Rusman. (2010). Model-model Pembelajaran: Mengembangkan Profesionalisme Guru. Jakarta: PT. RajaGrafindo Persada. 
[22] Sugiyono. (2008). Metode Penelitian Kuantitatif Kualitatif dan R\&D. Bandung: Alfabeta.

Aco Karumpa, born in Wajo, South Sulawesi on 31 December 1972. He is the son of the couple, father, H. Baso Karumpa and mother, Hj. Andi Mareting. He is married with Andi Najwa and has two children, Andi Chaerul A. Fawzy and Andi Muhammad Farhan Fahrezy.

He studied at SDN 169 basis Paung (graduated 1984), continuing education at SMPN 2 Tempe (graduated 1987), secondary education in SPG Sengkang (graduated 1990). Subsequently, he continued his undergraduate education at the Teachers' Training College Ujung Pandang (graduated 1994), graduate studies in the PPs Makassar State University (graduated in 2002), and Doctor of Education at the State University of Makassar. He had the opportunity to follow the Sandwich Program at Flinders University, Adelaide, South Australia from October to December 2012.

He worked as a teacher since 1994. He became principal at SMPN 1 Sajoanging (2005-2008), SMPN 4 Tanasitolo (2008-2013), SMPN 3 Sengkang (2013), and SMPN 1 Sengkang (2013-2015). This time, he became a school inspector in the office of the District Education Office Wajo.

He was active in organizations such as KNPI, PGRI, IDI, and Karang Taruna. He is also active as a facilitator in PRIORITIES USAID since 2013 to now.

Paturungi Parawansa, was born in Takalar on February 1, 1937 from the father, I Mannaggalli Daeng Nyonri and mother, I Basse Masigi Daeng tacos. He was married to Juliana Daeng Nginna on 9 September 1957.

He attended elementary school in Volks School Takalar. Furthermore, he went on to Cursus Var Volks Onderwys (CVO) Takalar. He continued his education again to SGB Makassar (graduated 1954). Subsequently, he completed his education at the SGB. He returned to continue higher education in FKIP Hasanuddin University in Gorongtalo. He wrote his thesis with the title 'Sinrilik I Datoe Moeseng, Sebuah Epos Mangkasarak'. He was educated at the Teachers' Training College Doctoral Malang (completed 1981). He won a Professor in 1990. He got the position as Chairman of the Parliament of Gowa (1971-1976). He also got a job as Rector of IKIP Ujung Pandang for two periods (1982-1986 and 1986-1991). Furthermore, he has life experience as a member of parliament of the MPR (1999-2004). He was listed as a member of the organization 'The International Council on Education for Teaching (ICET) in the USA. He has participated in 'International Seminar on Linguistics at SEAMEO RELC, Singapore (1990). He is earned several awards, among others: (1) The Best Men Gowa (1997) and Best Men KabupatenTakalar (2000).

Mansyur, was born in Dompu, NTB December 25, 1968. He was the second child of five children with a parent, father, H. Gani Saleh and mother, St. Hajar Abakar. Sri Hastati He married and had a son, Aura Fadilah Zahra.

He attended elementary school (graduated 1980), UP (graduated 1984), and high school (graduated in 1987) in Dompu, NTB. He continued his undergraduate education at the Teachers' Training College Ujung Pandang majoring in Mathematics Education (graduated 1991). He became a mathematics lecturer at the Faculty of Engineering, University of Makassar until now. He follow s the Pre-Masters in Mathematics at the Bandung Institute of Technology (1994-1995). He continued the master degree in Science of Mathematics at the Institute of Technology Bandung (completed 1998). He followed Sandwich Program to Utrecht University Netherlands for one semester (2008-2009) to explore the item response theory and statistics. He holds a Doctoral degree field of Measurement and Testing (Pscho Education) at the Yogyakarta State University in 2009. In 2010, he received the title of Profe ssor in the field of educational research and evaluation of the Ministry of Education and Culture of the Republic of Indonesia.

Books he has written and published are: (1) Mathematics, (2) Learning Outcomes, (3) Assessment of Early Childhood Development, (4) Assessment of Learning in Schools.

Mohammed Saleh, was born in the Deep South Sulawesi dated December 31, 1975. He attended elementary, junior high and high school in South Sulawesi. He continued his undergraduate education (S1) at IKIP Ujung Pandang (completed 1999), graduate studies in the Makassar State University (completed in 2004), and Doctor of Education at the State University of Malang (completed 2009).

He worked as a lecturer at the State University of Makassar in the Department of Language and Literature Education Indonesia. During a lecturer, he writes books and articles, including: (1) Sociolinguistics, (2) Integration of the Subconscious Mind in the curriculum in 2013, (3) Linguistics Religious, (4) endeavor Establishing Religious Linguistic Paradigm.

In the course of his career, he gained several achievements and awards, such as: (1) Outstanding Lecturer Faculty Exemplary III level (2005), (2) Examiners on Doctoral Promotion Exam on behalf Kasma F. Amin and Muhammad Amin (2015).

In addition to being a lecturer, he was active in the organization, such as: (1) The Board Members of the Development Department of Language and Literature Indonesia (2000 to present), (2) The Board IKA Commissariat FBS (2005-2010 and 2010 to present), (3) Society Indonesian Linguistics (2001 to present). 